\title{
Pragmastylistic Analysis of Fusun's Linguistic Realization of Positive Politeness Strategies in Pamuk's The Museum of Innocence
}

\author{
Chatarini Septi Ngudi Lestari ${ }^{1}$ \\ chatarinisnl@gmail.com ${ }^{1}$ \\ Sekolah Tinggi Ilmu Bahasa Dan Sastra Satya Widya ${ }^{1}$
}

\begin{abstract}
The study examines the linguistic realization of the positive politeness strategies used by Fusun in the novel written by Orhan Pamuk entitled The Museum of Innocence through pragmastylistic perspective. The aim of this study is looking into and describing how Fusun realizes those strategies when she communicates with Kemal. The data used are Fusun's utterances which concerned with positive politeness strategies. The data analysis used descriptive qualitative because data are collected in the form of speech and a content analysis method in order to reach a greater comprehension of what occur the recent situation in the novel. The findings revealed that presuppose/ raise/ assets common ground, avoid disagreements, and using identity markers were the strategies most often applied by Fusun. In addition, her utterances are also realized through grammatical cohesion and lexical cohesion. Those strategies applied to show her closeness and solidarity so that it made her interlocutor feel good.
\end{abstract}

Keywords: Linguistic realization of positive politeness strategies, pragmastylistics, Fusun, Pamuk, The Museum of Innocence

\section{Introduction}

Linguistic politeness is very important in daily life of human-beings, therefore, politeness is never an outdated theme because politeness is always essential for humans to have successful communication with others. Nowadays, politeness has developed widely in various types of varieties that pursue the development of each field, even politeness researches have been in the central of devotion for three decades [1, p. 1411]. Politeness describes the prosperity of human culture that is taught from generation to generation. This is the unique value of society that distinguishes it from one group to another. Its uniqueness lies in the difference in rules and functions that underlie the use of politeness, because it will only work in their own community. Politeness is a means that is applied to make awareness of the faces of others and consequently, plays a vital function in communication. In other words, it can be said that linguistic politeness plays an important role when building interpersonal relationships of mutual respect in any communication situation, including in fictional communication by characters. Politeness means an instrument used to express the consciousness into the face of another person. It can be captured that the face may be damaged, held or increased during interactions. In interacting, some utterances can be considered as threats. Threats can occur to positive faces and negative faces, or even to both at the same time. To minimize the risk of threats to the face, a strategy is needed. The choice of words is as part of a politeness strategy

The choice of strategy depends on the need for politeness. This means that in choosing a particular politeness strategy is determined by three elements. They are power, 
social distance, and level of coercion. In other words, strategies form a hierarchy of strategies that will achieve the highest level of goals. There are four kind strategies of politeness offered by Brown and Levinson [2], they are bald on-record, positive politeness, negative politeness, and off record. Referring to this study, the focus is on the strategy of positive politeness performed by Fusun, one of the protagonists of Pamuk's The Museum of Innocence when communicating with Kemal, another protagonist. This study aims to determine the extent to which these strategies are used by Fusun and how these strategies are manifested in her speech. In order to reach these goals, this research was conducted by applying the pragmastilistic approach and Brown and Levinson's theory of politeness

Pragmastylistics is the study of linguistic speech forms in stylistics and pragmatics [3, p.16]. Davies [4, p.106] also states that the recent treatment of language styles has moved from study of linguistic speech forms to a broader interest in pragmatics). Additionally, Norgaard, Montoro, and Busse [5, p. 3] emphasizes that pragmastylistics is concerned with the use of language and the importance of situational elements such as, the linguistic, social, cultural and author context of the production and reception of texts. In addition, they also state that pragmastylistics primarily focuses on dialogues, or interpersonal communication and commitment to linguistic aspects such as speech acts, discourse markers, politeness strategies, and so on, which makes it a useful method to drama and other kind text of discourse In other words, it can be said that pragmastylistics studies the way how the authors use their creativities, instead of language, joined the extralinguistic situation and communicate their messages through their literary works and finally it can result in internal changes of the readers.

Literature exploits the entire linguistic repertoire to convey its aesthetic form and message. In this regard, throughout its history linguistics and literature are two different disciplines, but they cannot be separated from each other. This relation has been claimed and tackled by works of scholars such as Carter and Simpson [6] who attempt to establish such relation in which stylistics tries to combine both approaches. Stylistics emerges as a response to the subjectivity and impressionism of literary studies. It tries to replace the subjectivity with explicit and systematic description and analysis. Stylistics bridges the inequality between literary studies and linguistic analysis. It is a gateway to the interpretation of literary works that helps identify their purpose, goals and effects. Since language functions as a medium in performing literary works, the interpreting and finding out literary works' objectives, influence and intentions is the significant field of the study that brings literature and linguistics altogether and establishes the firm relation that holds between them [7, p. 117]. In addition, both as the interdisciplinary subject, it is no doubt new insight will emerge into the rich potential for the enhancement of style studies by the rapidly expanding field of pragmatics $[8$, p. 10].

\section{Politeness and Face}

The theory of politeness has been developed by Brown and Levinson [2]. They announced the idea of 'face' in their work. The face is a public self-image in which each component of community desires to maintain themselves [2, p. 61]. The idea of a 'face' builds on Goffman [9, p. 5]. The face is appreciated as somewhat that indicates the public self-image. In other words, the face is the self-image that the individual wants not only to show to others, but also the recognition that other people have their own needs. Perhaps it is as an investment that cannot only be lost, but also maintained or enhanced. 
Kitamura [10, p. 1] states that Brown and Levinson's design involves two different things. They are the basic theory which referring to the characteristics of politeness and how it works in communication and a listing of politeness strategies. During communication, the communication has an interest in sustaining two different kinds of 'faces'. A positive face is a want to be respected and to keep a positive self-image. It can be concluded that a positive face involves a person's want to be loved, respected and adored. The negative face is the privilege to abandon of action and abandon from coercion. The negative face is the want not to be disturbed and to have complete private place and autonomy. It can be concluded that the negative faces presuppose one's want to act easily, without constraints or coercion from another [11, p. 72]. Brown and Levinson [2] argue that entering into a communities, one has to recognize and demonstrate a consciousness of the 'face', public self-image, sense of self, of the person being addressed. Therefore, it is the characteristics of cultural differences that speakers must appreciate each other's hopes about self-image, consider their senses, and shun facethreatening actions (FTA) [12, p. 45].

Referring to the idea of 'face' and 'politeness', it is presupposed that there are two different characteristics, namely positive politeness and negative politeness [13, p. 577]; [10, p. 1]; and [12, p. 44-45]. Positive politeness is stated by fulfilling positive faces in different ways, namely (a) by showing the sameness between interaction actors, or (b) by stating admiration for the other person's self-image. Even so, negative politeness can also be performed in different ways, namely (a) by keeping another person's face (negative or positive) by reducing face threatening actions (FTA), such as giving advice and disapproval; or (b) by fulfilling a negative face by showing esteem for the recipient's right not to be imposed. From the description above, it can be said that politeness is presented not only to minimize FTAs, but also to fulfill the faces of the interlocutor regardless of whether an FTA appears or not.

\section{Linguistic Realization of Positive Politeness Strategies}

Politeness strategy is a strategy exploited to avoid disturbances on the listener's face. As explained by Brown and Levinson [2] politeness strategies were created to protect the face of the listener because face refers to the esteem for oneself and sustain that self-respect in public or in restricted circumstances. Every strategy offers within different levels of politeness, so the addresser will keep in mind the threat level faces in selecting the applicable strategies of language realization of politeness. There are four types of politeness strategies, called super strategies, which are used to achieve successful communication [2, p. 91-227]. Referring to this present research, the analysis focuses on the positive politeness strategies used by Fusun when she communicates with Kemal in Pamuk;s novel The Museum of Innocence. Positive politeness is used to show solidarity with others. Positive politeness is presented by fulfilling positive faces in different ways, namely (a) by showing similarities between interaction actors, or (b) by uttering admiration for the self-image of the interlocutor. Positive politeness strategies are deliberated to shun taking offense by accentuating friendliness or attractiveness of solidarity with others [2, p. 48] and [14, p. 14]. Positive politeness is concerned with hearer's positive face, the positive self-respect they assert for themselves.

The positive politeness of language realizations represent natural language activities among the people closest to each other in which interests and personalities agree with each other, prejudices that indicate shared desire and shared knowledge are replaced. Positive 
politeness is operated as a kind of figurative enlargement of closeness, to apply a similarity or sharing of desires to some extent even among outsiders who consider themselves, for the goal of communication [2, p. 101]. Furthermore Brown and Levinson [2, p. 103-129] state that positive politeness strategies are realized into fifteen strategies, namely: strategies (1) Noticing by paying attention to $\mathrm{H}$ (activities, wishes, necessities, things), such as "How this beautiful vase! Where does it come from? ", strategy (2) Exaggerating (attention, promise, compassion with $\mathrm{H}$ ), as in" How a wonderful your writing! ", strategy (3) Increasing the interest to hearer, for example" You always do the plates! I will do it this time", strategy (4) Using an identity tag in the group, for example, "Help me with this book here, would you dear?", strategy (5) Finding a deal, such as in" Is not your new house a beautiful color! ", Strategy (6) Avoiding disagreement, as in "Yes, but..." strategy (7) Presupposing / raising /emphasizing commonalities, as in "What about letting me have one of that cookies!, strategy (8) Making Jokes, as in "Ok, I handle that cookie right now?", strategy (9) Asserting or presupposing speaker's knowledge and concerning for hearer's wishes, as in "I know you can't have a party, but this one would be great - come over!" (demand / supply), strategy (10) Offering, promising, for example, "I'll stop by next week", strategy (11) Being optimistic, for instance, "You will lend me your lawnmower for the weekend, I hope", strategy (12) Including S and $\mathrm{H}$ in activities, such as "Let's do it together", strategies (13) Giving or asking for the reasons, as in "Why do you not lend me your cottage for the weekend? ", strategy (14) Assuming or emphasizing exchange, as in" I will do X for you if you do Y for me ", and strategy (15) Giving presents to $\mathrm{H}$ (entities, compassion, kind, ,support).

\section{Research Methods}

The data source used was a novel written by Orhan Pamuk, a Turkish novelist, entitled The Museum of Innocence [15], which published in 2008 two years following he won the Nobel prize in Literature. Thus, the novel translated into English by Maureen Freely in 2009. Lazzarich [16, p. 111] states that The Museum of Innocence is an interesting novel because the plot of this novel refers to social conditions in Turkey (it set in Istanbul, Turkey 1975) and at the same time the creatively changes the literary form of a love novel, therefore it can be understood as an avant-garde postmodern change from the traditional genre. The Museum of Innocence talked about a sad and tragic love story experienced by Kemal and Fusun. Kemal, an unmarried thirty-year-old descendant of one of the richest families in Istanbul, promised marriage to Sibel, the daughter of another prominent clan. However, Kemal meets Fusun, eighteen, a beautiful shop girl, and a poor long-distance relationship, at The Sanzelize Boutique when he wants to buy a handbag for his girlfriend, Sibel. Unfortunately, the handbag is not a genuine Jenny Colon. The day after, Kemal went to The Sanzelize Boutique to return the fake handbag. From this kind of meeting-up, it has changed Kemal's entire life. Finally, they enter into a relationship. More or less 8 years later, they officially were to be engaged before getting married. Tragically, one day after getting engaged, Kemal and Fusun got accident and Fusun was dead.

The present research focused on the utterances which are produced by Fusun when she communicates with Kemal. Fusun utterances were chosen to determine which positive politeness strategies were categorized according to Brown and Levinson [2]. Positive politeness strategy originally ordered from number 1 to 15 in Brown and Levinson [2]. In this paper the linguistic realization of positive politeness strategy abbreviated RPPS- then followed by their number (for example RPPS-1 stands for linguistic realization of positive politeness 
strategy number 1). This research is descriptive qualitative because the data used in this study are utterances uttered by Fusun when she communicates with Kemal. As explained by Bogdan and Biklen [17, p.29] one of the characteristics of qualitative approach is the collection of data are in the form of sentences, clauses, words or expressions. The utterances are analyzed inductively and the result counted the frequency will produce quantitative data which are important for interpretation. So the quantitative data used in this research has function to corroborate the qualitative data and modify or strengthen the analytic findings [18, p. 56]. Besides, the researcher is as the key instrument since she has the authority to manage and determine data collection and analysis and decide the time to start and end the research [19].

In analyzing the identified data, she applies content analysis method. Borg and Gall [20, p. 512] assert that analysis of content is technique to account for objective, systematic, and qualitative in communication. Thus, content analysis techniques applied in all types of interaction, mostly written material, but other kinds of interaction, such as music, pictures, or movements, should not be excluded. Related to that statement, it is due that content analysis technique employs in this study because source of data is written material that is novel and data are utterances which are produced by characters. The use of content analysis techniques in this study is to reach a greater comprehension of what occur and how to explain the recent situation. As stated by Borg and Gall [20, p. 514] content analysis usually aims to achieve one of the types of goals, namely: (a) to produce descriptive information, it means content analysis used to provide descriptive information that can provide a greater comprehension of what is happening and how to explain the recent situation, (b) Cross-validate research findings, meaning content analysis is a useful tool for examining research findings obtained from research using other methods, and (c) Hypothesis testing, it means content analysis can be used to explore relationships and to test theories. In line with the aims of applying content analysis method above, the researcher conducts this research in order to achieve one of them that is to produce descriptive information since she wants to know any kinds of information from the novel The Museum of Innocence and get a better understanding the content of novel, including the story of the novel, the roles of characters and their characteristics, the relationship among the characters, the interaction among others.

\section{Result and Discussion}

After analyzing the utterances produced by Fusun when she converses with Kemal in the novel written by Orhan Pamuk entitled The Museum of Innocence concerning with linguistic realization of positive politeness strategies offered by Brown and Levinson [2], a number of positive politeness strategies can be seen in table 1, as follows:

Table 1: The Frequency of Using Linguistic Realization Strategy of Positive Politeness

\begin{tabular}{|c|c|c|c|c|c|c|c|c|c|c|c|c|c|c|c|}
\hline \multirow{2}{*}{$\begin{array}{l}\text { Addresser/ } \\
\text { Frequency }\end{array}$} & \multicolumn{15}{|c|}{ Realization of Strategy of Positive Politeness (RPPS) } \\
\hline & 1 & 2 & 3 & 4 & 5 & 6 & 7 & 8 & 9 & 10 & 11 & 12 & 13 & 14 & 15 \\
\hline Fusun & 4 & 3 & 14 & 35 & 21 & 39 & 46 & 0 & 3 & 5 & 8 & 12 & 5 & 2 & 0 \\
\hline
\end{tabular}

From the table above, it can be identified 197 utterances concerning with linguistic positive politeness strategies produced by Fusun. She uses 13 (thirteen) types of 15 (fifteen) types strategies of positive politeness proposed by Brown and Levinson [2] to realize her utterances when she communicates with Kemal. They are RPPS 1 (4 times), RPPS 2 (3 times), 
RPPS 3 (14 times), RPPS 4 (35 times), RPPS 5 (21 times), RPPS 6 (39 times), RPPS 7 (46 times), RPPS 9 (3 times), RPPS 10 (5 times), RPPS 11 (8 times), RPPS 12 (12 times), RPPS 13 (5 times), RPPS 14 (twice), while the strategies which are not used is RPPS 8 and RPPS 15. The strategies which are applied more often by Fusun are RPPS 7 Presupposing / increasing / emphasizing similarities RPPS 6 Avoiding disagreement, and RPPS 4. Using identification tags in groups. They are 46 times, 39 times, and 35 times respectively. Hence, in this paper it only describes those kinds of linguistic realization of positive politeness strategies which often appeared briefly.

Positive politeness strategy applies in order to reveal that the speaker wants to show her closeness and solidarity, make interlocutor feel good, and stress that she has a common goal. The expression appeared in Fusun's utterances by mentioning the act explicitly and directly, by using linguistic features to show closeness, such as address name/ nick name (Kemal), endearment term (dear), inclusive form (we), tag form (won't you), exaggerative form, ellipsis, and reciprocity. For example "Kemal, believe me, I no longer want to take this trip to Europe. I can't even speak the languages, and it makes me ashamed" [15, Ch. 76 p. 640]. This example contains a solidarity strategy so it classified into positive politeness strategy. Fusun uses an identity marker to repair Kemal's positive face. If Fusun's utterance is looked at a glance, it categorized into bald on-record strategy since she applied imperative syntactic structure 'believe me'. But if it is seen in detail, Fusun's utterance classified into positive politeness strategy because of the use of address form 'Kemal' including the generic name usually called identity marker. It can lessen imperative and even it might turn a command into a request. As suggested by Brown and Levinson [2, p.103] positive politeness strategy is a kind of social accelerator in which an addresser always tries to approach the target person. This strategy is usually used when the giver and receiver are close friends because the charges are small. Referring to these findings, the linguistic realization of positive politeness strategies is dominated by the use of presupposing / raising / asserting common ground, use of avoidance of disagreement, and use of identity markers in groups.

The linguistic realization of strategies of positive politeness in terms of presupposing / increasing / affirming similarity has the highest frequency (46 times). It is used by speakers in their spare time to be with their listeners, to show that almost all sentences in natural language encode the point of view with deixis. Deixis discusses the ways in which sentences are attached to specific elements of the context of their speech, including the participant's role in their speech and their spatial-temporal and social location. For example, the pronoun 'I' usually refers to a participant taking the role of a speaker, while 'now' refers to the time that includes the talk time, and 'there' refers to a place further away from the speaker than 'here' and so on. It can be seen in Fusun's utterance "They asked me about my whole life. They even asked why I got divorced. Even how did I support myself. They even asked me that. So I'm not going to Europe. I don't want visas from any of them" [15, Ch.76 p.640]. From the example it shows that Fusun told Kemal about the result of her visa interview. From the utterance can be described that the word 'they' refers to visa interviewers. In this case Fusun applied past tense to present tense. The tense shift function is to improve the closeness and attractive of the story. To show personal centre switch, it applied by combining pronoun 'I' and pronoun 'you' into 'we' inclusive, even though only hearer referred to, for instance, by using tag question with falling intonation, such as utterance "I didn't do any homework, Okay?" [15, Ch. 20 p. 115]. Besides, it also applied through presupposition manipulations, it applied if the speaker states as if it is assumed to be mutual. The utterances which refer to this kind which shown presuppose H's knowledge, for examples "You know perfectly well that 
you have no intention of helping me become a film star. There's no longer any need, after all." [15, Ch.79. p. 664].

The linguistic realization of strategies of positive politeness in terms of avoiding disagreement also had a higher frequency (39 times). Token agreement is the want to agree or seem to approve with the listener also manages to a system to pretend to agree, such as to respond to interlocutor "No, don't you say anything to her" [15, Ch. 6, p. 22] it is produced as a response to Kemal's question why Kemal did not say the same thing to Senay Hanim, the owner of The Sanzelize Boutique since the handbag Jenny Colon is not genuine. Pseudoagreement is used when the addressee agrees on an expression but not on the same assertion. It can be applied by using 'then' and 'so' as a conclusive signs. The examples of this strategy which used by Fusun when she communicates with Kemal are such as: "So you decided to wait until you had found a warm house?" [15, Ch. 13, p. 67]; "I'll be waiting to hear from you, then" [15, Ch.21, p. 21]; "All right, then" [15, Ch. 75, p. 622]. Fusun applied 2 (two) kind of conclusory markers 'then' and "so" to express her pseudo-agreement in order to avoid disagreement. Hedging opinion is as an alternative to avoid disagreement, $\mathrm{S}$ can choose not to be clear about her own opinion, so as not to appear disagreeable. Hedging is usually a feature of negative politeness, but hedging can also be used as a function of positive politeness using the 'sort', 'like', 'kind of', and 'in a way' of hedging. Fusun applied hedging opinion when she might be vague about her opinion when she converses with Kemal. Fusun's utterances which are related to her own vagueness are "Nothing like that ever happens here!" [15, Ch. 6, p. 20], "What sort of evil intentions?", [15,Ch. 59, p. 458], "I don't feel like it right now!" "I'm happy just like this." [15, Ch. 77, p. 652]. Hedging can also be applied to reduce FTAs in advising, analyzing, or protesting by hiding the purpose of the speaker, such as Fusun's utterance "Ah, to be worthy of you I need to see some of Europe, is that it? Well, I've also given up on the idea of marrying you." [15, Ch. 76, p. 640].

The linguistic realization of strategies of positive politeness in terms of using identity markers in groups has a high frequency (35 times). It is applied by the speaker in order to show as member of the group. The address forms applied in a situation without imposition to the hearer and with imposition to the hearer. If it is used without imposition, the terms are used to express intimacy or friendship, but if it is used with imposition, the terms are used to express the softener for imposition. Based on the analysis, Fusun applied both of them. The address form can be treated toexpress membership in the group which include the generic names or nicknames, such as in Fusun's utterances "Kemal, I want you to read this carefully" [15, Ch. 56, p. 414]; "I have no doubt about that, Kemal Bey!"[15, Ch. 58, p.446]; and "Never mind, my dear," "I'm just passing the time, you know" [15, Ch. 64, p.511].

Based on the analysis, Fusun's utterances also derived from elements of cohesion. They are grammatical cohesion and lexical cohesion. The utterances produced by Fusun are interrelated since each utterance as a response or answer to what the speaker inquires. The way how to create utterances is by using reference, substitution, ellipsis, and conjunction which are under-heading grammatical cohesion and repetition, synonym, antonym, and collocation which are under-heading lexical cohesion. For instance:

"Not at all, Cousin Kemal, I recognized you right away, but when I saw you did not recognize me, I thought it would be better not to disturb you." [15, Ch. 2, p. 5]. Fusun's utterances consist of the components of grammatical cohesion and lexical cohesion. The components which are used are personal references (I, you, me, it), adversative conjunction (but), and comparative conjunction (better). Those components are used to show who as a speaker, as an addressee, and what the relationship one part and other parts. Besides, repetition (see the bold italic typeface recognized-recognize) is also used which categorized into 
anadiplosis/ reduplication since repeated from the word in one line to the next. The use of repetition is to strengthen the information. The existence of grammatical cohesion and lexical cohesion make the utterances easy to understand.

\section{Conclusion}

After analyzing the utterances which are produced by Fusun as main character which are concerned with politeness strategies in the novel written by Orhan Pamuk entitled The Museum of Innocence through pragma-stylistic perspective, it can be drawn some conclusions related to the result of analysis. Politeness is elements used in communication and therefore plays an important role in communication. Speakers who want to reach their aims in communication cannot do without doing face threatening acts (FTAs). So the existence of strategies in communication is very important to reduce nuisance.

Referring to the result of the analysis Fusun applies positive politeness strategy because Fusun wants to shun violation by stressing kindness. Besides, she uses positive politeness strategy in order to keep positive face by showing intimacy and camaraderie, attracting to relationship, building interlocutor comfortable, and stressing the two interlocutors require the same end. In realizing of linguistic politeness strategy concerning positive politeness strategy Fusun applies thirteen linguistic positive politeness strategies. The order strategies applied by Fusun from the most employed to least employed is RPPS 7, RPPS 6, RPPS 4, RPPS 5, RPPS 3, RPPS 12, RPPS 11, RPPS 10, RPPS 13, RPPS 1, RPPS 2, RPPS 9, and RPPS 14, while RPPS 8 and RPPS 15 were not appeared. The prominent linguistic realization of positive politeness strategy used by Fusun is presuppose/ raise/assert common ground followed by avoid disagreement and use in-group identity markers.

Besides, Fusun's utterances derived from elements of cohesion, namely grammatical cohesion and lexical cohesion. The utterances which are produced by Fusun are interrelated since each utterance is produced as responses or the answer to what the speaker inquires. The way how to create utterances is by using reference, substitution, ellipsis, and conjunction. All of them are under-heading grammatical cohesion. Fusun's utterances derived from (1) reference, it consists of personal reference, demonstrative reference, and comparative reference. Personal reference appears dominantly in her utterances; (2) conjunction, it consists of additive conjunction, adversative conjunction, causal conjunction, and temporal conjunction; (3) substitution, especially nominal substitution; and (4) ellipsis, especially verbal ellipsis. Meanwhile lexical cohesion which appears in Fusun's utterances is repetition, synonym, antonym, and collocation. Repetition is more often appeared in Fusun's utterances. The use of repetition is to affirm, to strengthen the intensity of information, to avoid mistakes, and to make it easier to remember information.

\section{Acknowledgements}

I would like to say my thankfulness to Prof. Dr. Fabiola D. Kurnia, M.Pd., and Dr. Oikurema Purwati, M.A., M.Appl., who have inspired, guided, encouraged me in understanding linguistic analysis of literary data with patience, integrity, and dedication. I also express my gratefulness to Prof. Budi Darma, Ph.D. who has inspired me in selecting and choosing novel as source of data in my research. 


\section{References}

[1] A. Izadi. "Politeness in Spoken Review Genre: Viva Voce Context", PERTANIKA, 21 (4), pp. 1411-1429, 2013

[2] P. Brown and S.C. Levinson, Politeness: Some Universals in Language Usage. UK: Cambridge University Press, 1987.

[3] G.W. Turner, "Sharing, Shaping, Showing: The deep Uses of Language", The Pragmatics of Style, Great Britain: T.J. Press (Padstow), Cornwall, 1990, pp. 15-27.

[4] A. Davies, An Introduction to Applied Linguistics 2nd Edition: From Practice to Theory. Edinburgh: Edinburgh University Press, 2007.

[5] N. Norgaard, R. Montoro, and B. Busse, Key Term in Stylistics. London: Continuum, 2010.

[6] R. Carter and P. Simpson, Language, Discourse, and Literature: An Introductory Reader in Discourse Stylistics. London: Routledge, 1998.

[7] H. G. Widdowson, Stylistics and the Teaching of Literature. England: Longman, 1975.

[8] L. Hickey, The Pragmatics of Style. USA and Canada: Routledge, 1990

[9] E. Goffman, Interaction Ritual: Essays on Face-to-Face Behavior. New York: Pantheon Books, 1967

[10] N. Kitamura,"Adapting Brown and Levinson's 'Politeness' Theory to the Analysis of Casual Conversation”, in Proceeding of ALS2K, the 2000 Conference of the Australian Linguistic Society, 2000

[11] E. Black, Pragmatic Stylistics. Edinburgh: Edinburgh University Press Ltd, 2006

[12] J. Cutting, Pragmatics and Discourse. London: Routledge,2002.

[13] L. Hickey, "Stylistics, Pragmatics and Pragmastylistics" in Revue belge de philology etd'histoire. Tome 71 fasc. 3, 1993.Languesetliteraturesmoderns-Modernetaalenletterkunde,pp.573-586.in

http://www.perse.fr/revues/home/prescript/article/rbph_0035-

0818_1993_num_71_3_3890.; 1993.

[14] G. Yule, Pragmatics. Oxford: Oxford University Press, 2011.

[15] O. Pamuk, The Museum of Innocence, New York: Alfred A. Knopf, 2009

[16] M. Lazzarich, "A Creative Approach to a Literary Work in the System of Problem-Based Teaching", Metodicki Obsori 13, Vol. 6( 2011) 3, 2011

[17] R.C. Bogdan, and S.K. Biklen, Qualitative Research for Education: An Introduction to Theory and Methods. Boston: Allyn and Bacon Inc, 1982.

[18] M.B. Miles, A.M. Huberman, and J. Saldana, Qualitative Data Analysis: A Methods Sourcebook $3^{\text {rd }} \quad$ Edition, London: SAGE Publication Ltd, 2014

[19] R.K. Yin, Qualitative Research from Start to Finish. New York: The Guilford Press, 2011

[20] W.R. Borg and M. D. Gall, Educational Research: An Introduction (4 ${ }^{\text {th }}$ Edition). USA: Longman,1983. 